\title{
Gastric acid secretion in Indians with particular reference to the ratio of basal to maximal acid output
}

\author{
R. K. GOYAL, P. S. GUPTA, AND H. K. CHUTTANI \\ From The Gastroenterology Unit of the Department of Medicine, \\ Maulana Azad Medical College and Irwin Hospital, New Delhi
}

EDITORIAL SYNOPSIS In a study in northern Indian subjects there was no correlation between the body weight and the acid secretion under basal conditions and after maximal histamine stimulation. A significant correlation was observed between the volume secreted and its acid content for basal as well as for maximal acid output.

The recent development of the augmented histamine test by Kay (1953) and its modifications (Card and Marks, 1960; Marks, 1961) have provided a reliable tool for the assessment of acid gastric secretion. This test is reproducible and provides a quantitative estimation which makes it suitable for comparing the results of studies from different geographical regions and racial groups.

Marked variations in the prevalence and the clinical behaviour of peptic ulcer exist in various parts of the world (Watkinson, 1961). From his study, Dogra (1941) concluded that peptic ulcer was about 15 times more common in Madras state (south India) than in the Punjab (a state in north India). The factors responsible for such variations are not known. Gastric hydrochloric acid being one of the important factors in the pathogenesis of his condition, it is possible that the differences in the incidence and the clinical pattern of the disease may be related to the varying secretory behaviour of the population.

The present study deals with the results of the augmented histamine response in north Indian subjects with duodenal ulcer and normal healthy adults.

\section{MATERIAL AND METHODS}

The gastric acid secretory pattern was investigated in 33 duodenal ulcer cases and 22 controls. All the cases were males. The mean age of the control subjects was 28 years and those of subjects with duodenal ulcer was 27.8 years. The mean weight was $52.9 \mathrm{~kg}$. and $57.9 \mathrm{~kg}$. in normals and duodenal ulcer cases respectively.

All the duodenal ulcer cases were radiologically proved. Five of these were operated upon and an ulcer was demonstrated in all of them. None of these had any other associated disease which is known to influence the acid secretion. All the normal subjects used as controls were free from any disease and none had any abdominal symptoms.

In 18 subjects the test was performed more than once to assess its reproducibility.

The method employed was the same as described by Marks (1961). A wide-bore (16 Fr.) radio-opaque tube with large holes near the tip was passed through the nose, and the position of the tip adjusted in the lowest part of the stomach under fluoroscopic control. All the residual secretions were completely aspirated with a syringe and were discarded. Continuous mechanical suction was then applied, which was assisted by manual suction whenever required. Throughout the procedure the patient was put in a semirecumbent position and was urged to spit out any saliva present in the mouth. Half an hour after beginning the test, mepyramine maleate (Anthisan) $50 \mathrm{mg}$. was injected intramuscularly. The spontaneous secretions were collected for one hour and designated the basal acid output (B.A.O.). One hour after the commencement, histamine acid phosphate was injected subcutaneously in a dosage of $0.04 \mathrm{mg} . / \mathrm{kg}$. body weight. The secretions after histamine stimulation were collected for one hour as four 15-minute samples.

The total secretion in the entire hour was called the maximal acid output (M.A.O.) and its fraction secreted during the middle half hour was designated the 'maximal histamine response' (M.H.R.). The acidity of the samples was determined by titrating against freshly prepared -I N sodium hydroxide, using phenolphthalein as indicator. The results were expressed as milliequivalents of hydrochloric acid per hour for basal acid output and maximal acid output. The sample of secretion collected for the middle half hour after histamine stimulation was called the maximal histamine response (M.H.R.) in the 
past, because of Kay's (1953) observation that the maximal response of parietal cells to the subcutaneously injected histamine occurred during the middle half hour. In our cases also this was true for the majority but there were two out of 22 normal subjects and seven out of 33 duodenal ulcer cases in which the plateau of secretion was either in the last or the first half-hour period after histamine injection. This designation of the maximal histamine response to the middle half-hour sample is, therefore, not fully justified. For this reason the values for this component of post-histamine hourly secretion have not been discussed. Baron (1963a) suggested the term 'peak acid output' (P.A.O.), for the half hour component which shows the peak acid secretion after subcutaneous injections of histamine.

\section{RESULTS}

The mean coefficient of variation in duplicate tests in 18 subjects, calculated from the acid values, was $9.16 \%$ for the maximal acid output. The test was not well reproducible for the basal acid output (coefficient of variance 16.6\%).

BASAL SECRETION The results for the basal secretion of acid in the group under study are summarized in Table I. The volume of the juice and its acid content secreted by the stomach under basal conditions were $63.5 \mathrm{ml}$. and $2.99 \mathrm{mEq}$. $\mathrm{HCl}$ per hour respectively in the normal subjects compared with the corresponding values of $87 \mathrm{ml}$. and $5.46 \mathrm{mEq}$. $\mathrm{HCl}$ per hour in duodenal ulcer cases, a difference which is highly significant $(\mathrm{P}<0.001)$.

TABLE I

BASAL SECRETION OF ACID

\begin{tabular}{|c|c|c|c|}
\hline & Control & $\begin{array}{l}\text { Duodenal } \\
\text { Ulcer }\end{array}$ & $\begin{array}{l}\text { Value of } \\
P\end{array}$ \\
\hline $\begin{array}{c}\text { Number of cases } \\
\text { Mean } \\
\text { Volume (ml./hr.) }\end{array}$ & $\begin{array}{l}22 \\
63.5\end{array}$ & $\begin{array}{l}33 \\
87.04\end{array}$ & $<0.001^{1}$ \\
\hline $\begin{array}{l}\text { S.E. } \\
\text { Range } \\
\text { Mean }\end{array}$ & $\begin{array}{c} \pm 5 \cdot 3 \\
22-115 \\
2 \cdot 99\end{array}$ & $\begin{array}{c} \pm 5.69 \\
35-131 \\
5.46\end{array}$ & $<0.001^{1}$ \\
\hline $\begin{array}{l}\text { Acid (mEq./hr.) } \\
\text { S.E. } \\
\text { Range } \\
\text { 1'Highly significant }\end{array}$ & $\begin{array}{l} \pm 0.33 \\
0 \cdot 70-5 \cdot 40\end{array}$ & $\begin{array}{l} \pm 0.453 \\
0.63-10.32\end{array}$ & \\
\hline
\end{tabular}

Apart from the mean values there was a wide range in each group. The overlap of values in the controls and duodenal ulcer cases was considerable. About half $(16 / 33)$ of the duodenal ulcer subjects secreted more acid than $5.4 \mathrm{mEq}$. $\mathrm{HCl}$ per hour, which is the maximum value for the controls. Only one duodenal ulcer case secreted more than $10 \mathrm{mEq}$. $\mathrm{HCl}$. Over half $(12 / 22)$ of the controls secreted less than $3 \mathrm{mEq}$. $\mathrm{HCl} / \mathrm{hr}$. However, four out of 33 duodenal ulcer cases also had similar values.
Thus, about half the duodenal ulcer cases were basal hypersecretors and the majority of the others had B.A.O. values which were in the upper levels of the normal range.

HISTAMINE-STIMULATED SECRETION The results for 'maximal' acid output during the entire one hour in normals and duodenal ulcer cases are summarized in Table II. The duodenal ulcer cases have a mean acid secretion which is nearly twice the value in normal controls. The difference between the two groups for volume and acid values of M.A.O. is highly significant $(P<0.001$ in both cases). The range, however, was large and there was considerable overlap between the two groups. About one fourth of the duodenal ulcer cases had a maximal acid output over $28 \mathrm{mEq}$., but none of the normals secreted so much acid. On the other hand over half the normal subjects had values less than $14 \mathrm{mEq}$. per hour. Only one duodenal ulcer subject secreted less acid than $14 \mathrm{mEq}$./hour. Acid secretion between 14 and $20 \mathrm{mEq}$. per hour was seen in eight out of 22 normals and eight out of 33 ulcer cases. Between 21 and $28 \mathrm{mEq}$. $\mathrm{HCl}$ per hour was produced by 16 of 33 duodenal ulcer cases and two of 22 controls.

\section{TABLE II}

ACID SECRETION AFTER HISTAMINE STIMULATION (M.A.o.)

\begin{tabular}{|c|c|c|c|}
\hline & Control & $\begin{array}{l}\text { Duodenal } \\
\text { Ulcer }\end{array}$ & $\begin{array}{l}\text { Value of } \\
P\end{array}$ \\
\hline $\begin{array}{l}\text { Number of cases } \\
\text { Mean }\end{array}$ & $\begin{array}{l}22 \\
155 \cdot 3\end{array}$ & $\begin{array}{l}33 \\
215 \cdot 3\end{array}$ & $<0.001^{1}$ \\
\hline $\begin{array}{c}\text { Volume (ml./hr). } \\
\text { S.E. } \\
\text { Range }\end{array}$ & $\begin{array}{l} \pm 7.96 \\
94-217\end{array}$ & $\begin{array}{l} \pm 10 \cdot 0 \\
120-410\end{array}$ & \\
\hline $\begin{array}{c}\text { Mean } \\
\text { Acid (mEq./hr.) }\end{array}$ & $14 \cdot 48$ & $24 \cdot 38$ & $<0.001^{1}$ \\
\hline $\begin{array}{l}\text { S.E. } \\
\text { Range }\end{array}$ & $\begin{array}{l} \pm 0 \cdot 96 \\
9 \cdot 1-27 \cdot 3\end{array}$ & $\begin{array}{l} \pm 1 \cdot 5 \\
8 \cdot 16-61 \cdot 0\end{array}$ & \\
\hline
\end{tabular}

${ }^{1}$ Highly significant

RATIO OF BASAL TO MAXIMAL ACID OUTPUT The B.A.O./M.A.O. ratio was found to range between $4.7 \%$ and $45.3 \%$ in normals and $5 \%$ and $55 \%$ in duodenal ulcer cases. About one fifth of the duodenal ulcer cases and one out of 22 normal subjects has a ratio over $35 \%$.

RATIO OF BASAL TO PEAK ACID OUTPUT To produce data which could be compared with the findings of Baron (1963c), we analysed our data and calculated the value of peak acid output. It may be pointed out that our values for basal and peak acid output are not comparable to those of Baron (1963a; 1963c) because we have measured the acid value with phenolphthalein as indicator $(p \mathrm{H} 8.3$ to 8.5) while Baron titrated the specimens to neutrality with 
phenol red ( $p \mathrm{H} 7$ to 7-4). However, the relationship between the two and the ratio may be compared in the two studies.

The mean of the basal to peak acid output ratio was 14.88 (S.E. \pm 1.41 ) in normal subjects and 18.97 (S.E. \pm 1.70 ) in duodenal ulcer cases. This difference between the two verges on significance $(P<0.05)$.

CORRELATION BETWEEN BODY WEIGHT AND ACID OUTPUT No significant correlation was found between the body weight and the acid output under basal conditions or after histamine estimation in either normal subjects or duodenal ulcer cases. Coefficient of correlation, ' $r$ ', in controls was -0.05 for weight and B.A.O.; and $-\mathbf{0 . 0 8}$ for weight and M.A.O. In duodenal ulcer cases its value was -0.25 for weight and B.A.O.; and +0.05 for weight and M.A.O. ( $P>0.1$ in all cases).

CORRELATION BETWEEN AGE AND THE ACID OUTPUT In the present study the cases with extremes of age were not included. However, the normal subjects aged over 30 years secreted an average of $2.34 \mathrm{mEq}$. $\mathrm{HCl}$ under basal conditions and 13.49 after maximal histamine stimulation as compared with those under 30 years who had corresponding values of $3.36 \mathrm{mEq}$. and $15.28 \mathrm{mEq}$. $\mathrm{HCl}$ respectively. The difference of the acid output in the two groups was not significant $(P>0.05)$.

RELATIONSHIP BETWEEN BASAL AND PEAK SECRETION There was no significant correlation between the basal and the peak acid outputs in duodenal ulcer cases or the normal controls. The coefficient of correlation ( $r$ ) between the two was 0.345 in normals and 0.309 in duodenal ulcer cases $(P=0 \cdot 1)$.

RELATIONSHIP OF THE BASAL AND PEAK ACID OUTPUTS TO THEIR RATIO There was a significant correlation between the basal and the ratio in normal controls and in duodenal ulcer, the coefficient of correlation (r) being 0.772 and 0.852 respectively $(P<0.001$ for both the groups). This correlation, however, is spurious (Baron, 1963c). No correlation exists between the values for P.A.O. and the B.A.O./ P.A.O. ratio in either normals or duodenal ulcer cases $(r=-0.2745$ and 0.1803 in the two groups respectively; $p>0.1$ for both).

\section{COMMENTS}

The comparison of our values with the other published ones reveals some points of interest. The mean value for M.A.O. in our cases is similar to the values reported from other parts of this country (Ganguli, Narielvala, Rao, Bhat, and Benjamin, 1962; Vakil and Mulekar, 1963). This holds true for both the normals as well as duodenal ulcer cases. These observations are confirmed statistically. The value of $p$, of the difference between our values and those reported from Vellore, is $>\mathbf{0 . 2}$ in normals and $>0.5$ in duodenal ulcer cases. In contrast the M.A.O. values reported from England (Bruce, Card, Marks, and Sircus, 1959; Kay, 1953) and the United States (Marks and Shay, 1961) are about one and a half times higher than our values.

Provided that the hypothesis of the relationship between the maximal acid output and the 'parietal cell mass' is correct (Card and Marks, 1960) one

TABLE III

BASAL AND 'MAXIMAL' ACID OUTPUT REPORTED FROM VARIOUS CENTRES

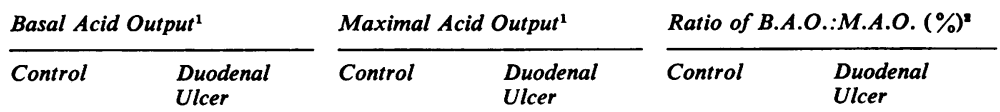

Delhi

Present study

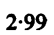

Vellore

(Ganguli et al., 1962)

Bombay

(Vakil and Mulekar, 1963)

Edinburgh

(Bruce et al., 1959)

Glasgow

(Kay, 1953)

Philadelphia

(Marks and Shay, cited by Marks, 1961) $2 \cdot 7$

${ }^{1}$ Mean values expressed in $\mathrm{mEq}$. $\mathrm{HCl}$ per hour

${ }^{2}$ Calculated from the mean values

$\begin{array}{lllll}5.46 & 14.48 & 24 \cdot 38 & 20 \cdot 1 & 22.4 \\ 7.07 & 17.20 & 25 \cdot 60 & 18.3 & 27.6 \\ 8.30 & 13.00 & 24.20 & 30.7 & 34.3 \\ 6.0 & 22.4 & 37.5 & 11 \cdot 1 & 16.0 \\ 6.8 & 22.2 & 37.0 & 9.9 & 18.3 \\ 5.4 & 28.2 & 39.6 & 11.6 & 13.7\end{array}$


would assume that Indians have a smaller parietal cell population in their stomachs compared with western subjects. The reasons and the significance of these observations are still to be evaluated.

Card suggested that the lower values for maximal acid output in our cases could simply be due to the lesser body weight of Indian subjects compared with western men, but no significant correlation was demonstrated between body weight and M.A.O. in our normal subjects or cases with duodenal ulcer. Our results are similar to those of Baron (1963b) who failed to find any significant correlation between body weight, surface area, or 'ponderal index', and peak acid output in 20 healthy men and 40 male duodenal ulcer subjects.

The age group of the cases included in a study may influence the results for acid output. It has been reported that acid secretion declines with age (Baron, 1963a). We did find higher M.A.O. values in normal subjects below 30 years than those over 30 years but the difference was not significant. Moreover, this study represents mainly young adults and subjects with extremes of age are not included. Therefore, it is unlikely that the factor of age could explain the lower M.A.O. values in our cases.

The explanation for this difference may lie in the differences in racial characteristics, variations in dietary habits, or nutritional status.

The values for basal acid output per hour in the present series and also in other Indian series (Ganguli et al., 1962; Vakil and Mulekar, 1963) appear to be slightly higher than those from western reports (Bruce et al., 1959; Kay, 1953; Marks and Shay, 1961). In view of the lower values in our cases, this may assume a certain importance.

The B.A.O./M.A.O. ratio (calculated from the mean values) is found to lie between 9.9 and $11.6 \%$ in normal subjects reported by western workers. In our cases this value is $20.1 \%$, which is about twice the western figure. The B.A.O./M.A.O. ratio of $18 \cdot 1$ was found in Vellore by Ganguli et al. (1962), whose study is comparable with ours. Moreover, the mean of the B.A.O./P.A.O. ratio in our normal subjects was 14.85 (S.E. \pm 1.42 ) which is higher than 5.4 (S.E. \pm 1.04 ) reported by Baron (1963c) in 20 normal male subjects, a difference which is highly significant $(P<0.001)$. All this would mean that Indians have a higher secretory mechanism under basal conditions than Europeans. The factors responsible for this higher basal secretory rate in our cases is not known, but it could be either neurogenic or hormonal.

Marks (1961) reported that the B.A.O./M.A.O. ratio was seldom more than $35 \%$ and never more than $43 \%$ except in cases of the Zollinger-Ellison syndrome. In the present series one normal subject had this ratio of $45 \cdot 3 \%$. Marks, Selzer, Louw, and Bank (1961), however, cited a patient who had basal secretion which was $42 \%$ of the maximal acid output. This patient showed evidence of hyperplasia of Brunner's gland in the first and the second part of the duodenum. It was suggested by those workers that gastrin was presumably related to rather unusual secretory status in that patient. This case may have some bearing on the higher B.A.O./M.A.O. ratio in our subjects. It would be of interest to note that one subject who was investigated as a normal control had a B.A.O./M.A.O. ratio of $59 \cdot 1 \%$. He was dropped from the group of normal controls, as on radiological examination he showed prominence of the mucosal folds in the stomach, duodenum, and upper part of the jejunum. There was no evidence of ulceration or deformity of the duodenal bulb.

The significance of the higher percentage of maximal secretory capacity under basal conditions is not clear. It would be interesting to see if it can be related to the remarkable geopathological peculiarity of the preponderance of duodenal lesion in peptic ulcer cases in India (Dogra, 1941). The B.A.O./ M.A.O. ratio in ulcer cases, calculated from the mean values, was found to lie between 13.68 and $18.38 \%$ in western studies (Bruce et al., 1950; Kay, 1953; Marks and Shay, 1961). In our cases this value is $22.4 \%$, which again is higher. Moreover, four duodenal ulcer cases secreted basal acid which was more than $43 \%$ of the M.A.O., a situation akin to that in the Zollinger-Ellison syndrome (Marks, 1961).

The mean of the B.A.O./P.A.O. ratio in our duodenal ulcer cases was 18.97 (S.E. \pm 1.7 ) which is higher than the mean of the B.A.O./P.A.O. ratio of $8 \cdot 71$ (S.E. $\pm 1 \cdot 20$ ) reported by Baron (1963c) in male duodenal ulcer cases (the $\mathrm{p}$, of the difference between the two is $<0.001)$. The higher B.A.O./ P.A.O. ratio, together with the lower maximal acid output in our duodenal ulcer cases, may be of significance, and may reflect upon the ultimate management of our cases of duodenal ulceration.

\section{SUMMARY}

The gastric acid secretory pattern was investigated in 33 duodenal ulcer cases and 22 normal healthy north Indian males with the 'maximal' histamine response.

There was no correlation between the body weight and the acid secretion under basal conditions and after maximal histamine stimulation. A significant correlation was observed between the volume secreted and its acid content for basal as well as for maximal acid output.

No correlation was found between values for basal and peak acid output. 
The maximal acid output values in our cases are lower than those reported in western subjects.

The basal to maximal acid output ratio in Indian subjects, both normals as well as duodenal ulcer cases, is significantly higher than that in western subjects. The significance of these variations has been discussed.

We are grateful to Mr. T. N. Sugathan for the statistical analysis of the data and to Messrs. Pfizer Pharmaceuticals who provided a grant to carry out this study; to Dr. O. P. Bhardwaj, Professor of Radiology, and his staff for their kind cooperation. Our thanks are also due to Dr. P. C. Dhanda, Director of the Maulana Azad Medical College and associate hospitals, New Delhi, for permission to publish this material.

\section{REFERENCES}

Baron, J. H. (1963a). Studies of basal and peak acid output with an augmented histamine test. Gut, 4, 136-144.

(1963b). Peptic ulcer, gastric secretion, and body build. Ibid., 5 , 83-85.

- (1963c). The relationship between basal and maximal acid output in normal subjects and patients with duodenal ulcer. Clin. Sci., 24, 357-370.
Bruce, J., Card, W. I., Marks, I. N., and Sircus, W. (1959). The rationale of selective surgery in the treatment of duodenal ulcer. J. roy. Coll. Surg. Edinb., 4, 85-104.

Card, W. I., and Marks, I. N. (1960). The relationship between the acid output of the stomach following 'maximal' histamine stimulation and the parietal cell mass. Clin. Sci., 19, 147-163.

Dogra, J. R. (1941). Studies on peptic ulcer in South India. Part IV: Incidence of peptic ulcer in India with particular reference to South India. Indian J. med. Res., 29, 665-676.

Ganguli, P. C., Narielvala, F. M., Rao, P. S. S., Bhat, H. S., and Benjamin, V. (1962). 'Maximal' (augmented) histamine test: assessment of gastric acid secretion in normal and duodenal ulcer patients in South India. Presented at the Annual Conference of the Indian Society of Gastroenterology, Indore, 1962.

Kay, A. W. (1953). Effect of large doses of histamine on gastric secretion of $\mathbf{H C l}$ : an augmented histamine test. Brit. med. J., 2, 77-80.

Marks, I. N. (1961). The augmented histamine test. (Editorial.) Gastroenterology, 41, 599-603.

- and Shay, H., cited by Marks, I. N. (1961).

-, Selzer, G., Louw, J. H., and Bank, S. (1961). Zollinger-Ellison syndrome in a Bantu woman, with isolation of gastrin-like substance from the primary and secondary tumors. I. Case report. 41, Ibid., 77-86.

Vakil, B. J., and Mulekar, A. M. (1963). Augmented histamine test. Presented at the Annual Conference of the Indian Society of Gastroenterology, Calcutta, 1963.

Watkinson, G. (1961). Geographical aspects of peptic ulcer. In Modern Trends in Gastroenterology, 3rd series, edited by W. I. Card, pp. 23-45. Butterworth, London. 